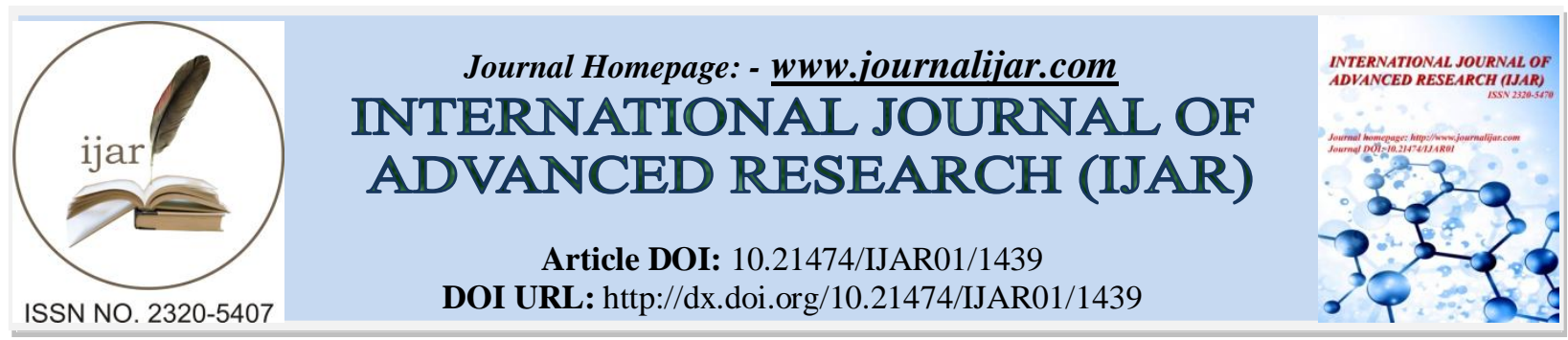

RESEARCH ARTICLE

\title{
DISSEMINATING LEADERSHIP INNOVATION TO AFFIRMWIDYAISWARAAS THE AGENT OF CHANGE (CASE STUDY ON BOARD OF TRAINING AND DEVELOPMENT, EAST JAVA PROVINCE, INDONESIA).
}

Dr. Hary Wahyudi.

Widyaiswara/ Lecturer in Board of Training and Development.

\section{Manuscript Info}

Manuscript History

Received: 12 June 2016

Final Accepted: 19 July 2016

Published: August 2016

Key words:-

Innovation, leadership, widyaiswara, agent of change.

\section{Abstract}

One of the assesment components to get an $\mathrm{A}$ in accreditation is the role of coaches (widyaiswara) in showing their ability and comprehension of substances based on experiences as consultants, researchers, and practitioners beyond the institution; as well as in improving their capacity as widyaiswara by publishing scientific writings in the form of books, proceedings, or academic journals.

Besides, the assesment is also based on the outcome from the training program (diklat), specifically measured by the quality of the outcome culminated by the participators during the programs, as well as the implementation of change/ transformation and the actualization of values within the institution.

As the agent of change, widyaiswara are the selected individuals/ groups to pioneer the transformation; the role models who are able to reflect integrity and capability within the organization. Widyaiswara, the agent of change, are responsible to promote and to be the role models in doing their responsibilities.

Copy Right, IJAR, 2016,. All rights reserved.

\section{Background of the Study:-}

1In early 2016, Public Administration Institute provides accreditation to all government agencies, including the education and training institution (diklat). East Java's Training Agency (Bandiklat Jatim) got the A (excellent) score of accreditation. Accreditation is a feasibility assessment for training institutions in organizing the Leadership Training II, III, IV and Training III, II and I. The purpose of accreditation is to improve the quality, efficiency, accountability of training and development.

One of the assesment components to get an A in accreditation is the role of coaches (widyaiswara) in showing their ability and comprehension of substances based on experiences as consultants, researchers, and practitioners beyond the institution; as well as in improving their capacity as widyaiswara by publishing scientific writings in the form of books, proceedings, or academic journals.

Besides, the assesment is also based on the outcome from the training and development program (diklat), specifically measured by the quality of products/ outcome culminated by the participators during the programs, as well as the implementation of change/ transformation and the actualization of values within the institution. 
The outcome (results) from the training participants are disseminated to users (institutions) and to the stakeholders. Dissemination is done by the display, the collection and documentation of the library, websites, exhibitions and alumni gathering.

This paper is based on the argument about the importance of researching / reviewing promotions and innovations made by the participants of Leadership Training Level III and Level IV to affirm East Java Training Agency as a source of the agents of change.

Nowadays, it is inevitable that the willingness to innovate and the ability to innovate in bureaucratic milieu remains low. Innovation is still a strange thing, is not preferred, even tend to be avoided because of a misconception that innovation is something that is not in line with the policy.

This condition of misconception must end. Government bureaucracy needs to be convinced that innovation in the public sector is exhilarating and easy to be done by the government officers.

In the management system of employee affairs, structural officers play a crucial role in planning the implementation of the agency's activities. One of the roles includes leading subordinates and all strategic stakeholders to carry out these activities effectively and efficiently. This task has demanded leadership competencies, i.e. the ability to influence and mobilize subordinates and strategic stakeholders in implementing the planned activities.

To be able to form a structural official figure as mentioned earlier, the implementation of Education and Leadership Training (Diklatpim) aims to equip participants with the competencies necessary to become an innovative leader, providing training that enables participants will be able to apply its existing competencies.

In the implementation of Diklatpim, participants are required to demonstrate their performances in designing a change or tranformation in their work unit, and also lead the change or transformation to yield significant outcome.

Thus, transformation or reform is expected to produce graduates who not only have the leadership competencies, but also able to demonstrate their performance in leading change/ transformation and spread the spirit of novelty through the promotion of innovation that has been designed and implemented during the training. A leader of change has to be able to spread the spirit of novelty to innovate in the public sector, more particularly, willingnes to inovate and ability to innovate.

\section{Problem Statement:-}

As stated in reference / guidelines concerning the management of the State Administration Institute laboratory of innovation, it is emphasized that laboratory management innovation pursued through five phases: drum up, diagnosis, design, deliver and display (promotion).

This study is limited to concern on the last stage of the phase, which is the display (promotion). Thus, the following question is imposed: "How is the innovative outcome of Leadership Trainee disseminated in order to affirm Badan Diklat Jatim as the agent of change?"

\section{Methodology:-}

This reearch focuses on the strategies of collecting and analysing empirical data or evidences. Furthermore, this study employs qualitative approach; in which data are obtained through experiment, field research, and library research as well.

Qualitative approach is applied in this research in order to objectively describe the problem, interpret the facts, and avoid biases. Research findings are then classified systematically and expected to answer the problem statement.

In order to conduct qualitative research, it is necessary to observe the innovation project of trainees, followed by collecting data and analytically describing it. At least there are six systematic steps taken in this study, namely:

1. Observation through focused group discussion with trainees.

2. Description and analysis on coaching and counseling with trainees.

3. Description and analysis on brainstorming of innovation projects. 
4. Description and analysis on the implementation of innovation projects.

5. Data collection of the promoted innovation projects and products/ outcome.

6. Analysis on proper recommendation, further commitment, and sustainable implementation.

Qualitative approach which is applied in this study constructs reality and meaning, focuses on the process and occasions interactively. Authenticity and originality are the keys which are limited on situation, cases and subjects, thematic analysis, and participatory observer (Neuman14).

Paradigmatic assumption of this research is based on the subjective reality of participants. The researcher interacted with the participants, and the interaction is by nature informal, biased, subjective, inductive, and constructed simultaneously. The reseach design is developed, categorized, identified, and contextually related. Pattern and theories are created for better comprehension. Accuracy and reliability are made through verification (Creswell 5).

\section{Analysis:-}

The analysis of this study is focused on answering the problem statement and describing how the outcome of Leadership Training III and IV are promoted and implemented.

Focus of analysis is the 83 working papers compiled by 83 participants of Leadership Training III and IV -which was conducted in 2015 in Badan Diklat campuses in Surabaya and Malang, participated by trainees from SKPD of East Java Government, SKPD of East Java cities and districts, and other participants from outer East Java.

Data analysis of this research is aimed to describe the dissemination of novelty through the promotion of innovation of Leadership Training, further listed as follows:

1. Varieties of innovations created by 83 participants, consisting trainees of Leadership Training III and IV year 2015;

2. Products of innovation/ training outcome created by trainees/participants which are promoted by either participants, organizers, or coach.

3. Mass media, electronic media, and publication tools of innovation products used for disseminating novelty;

4. Description of supports and obstacles -and ways to overcome- in disseminating novelty through promotions of innovation products of Leadership Training.

\section{Theoretical Framework:-}

Dissemination is a practice of transmitting information to certain groups or individuals in order to stimulate the ability to accept and to make use of the information. Furthermore, dissemination is a process of spreading the idea of innovation that is planned, directed, and processed. Dissemination of the idea of innovation is done thoroughly through discussions or forums that result in the agreement of implementing the ideas of innovation.

The word 'dissemination' is not commonly used in daily conversation, otherwise it is mostly found in academic field -for example, "dissemination of research outcome", or in bureaucratic field it is commonly known as "dissemination of training outcome", that means transmitting the training outcomes to other employees.

More specifically, dissemination is defined as the widely transmission information, ideas, policies, and research outcomes. Dissemination is also regarded as "is a practice of transmitting information to certain groups or individuals in order to stimulate the ability to accept and to make use of the information."

\section{E.1 Promotion Theory:-}

The idea of promotion, or further known as promotion mix, was proposed by Philip Kotler (2002). Promotion mix consists of five main 'tools', namely advertising, personal selling, sales promotion, public relations/ socialization, and publications. These promotion tools are basically the ways to communicate with the 'target'/ 'customers'. Those sorts of promotion tools must be used effectively to obtain the optimum marketing result and to reach the target sales for a company.

In marketing and promotions, there are some aspects that need to be concerned. Those aspects include the product knowledge, its competitive advantage, and its influence or benefits of use. 
Promotion aims to 'promote', or in other words to persuasively inform people about any products or programs. Promotion is by nature should be done informatively, persuasively, and commercially. In addition, promotion especially promoting a program- is also used as a way to 'solve the problem' or to 'offer a change' through the program being promoted.

InStrategi Promosi YangKreatif(Rangkuti,2009:51), there are four fundamental objectives of promotion, namely:

1. To Modify Behavior Promotion aims to modify/change people's behavior or perspective toward certain issues. For example, in an organization, promotion of a program aims to make people who are resistant to change become adaptive to change.

2. To Inform Promotion is by nature informative. In marketing, aspects being informed or promoted will include product's use, price, quality, competitive advantage, and so on.

3. To Influence Promotion aims to influence or encourage people to buy the products being promoted. In an organization, promotion aims to influence people to follow the ideas or programs being promoted.

4. To Remind Promotion aims to sustain the existence of a product by reminding people about the product or the program.

\section{E.2. Innovation Theory:-}

One of the proponents of innovation theory or ideas is Djamaludin Ancok. In his book Psikologi Kepemimpinan \& Inovasi (2007), as cited on Handbook of Innovation of Public Administration (LAN,2014), innovation consists of 8 aspects, namely process, method, technology, product, concept, structure, correlation, and human resource development.

Innovation can no longer be regarded as an alternative, but rather it is the main option to be conducted in order to improve economic growth, national competitiveness, and public welfare. Innovation is a key to improve economic growth, national competitiveness, and public welfare(Handbook of Innovation of Public Administration, LAN 2014).

\section{Widyaiswaraas the Agent of Change:-}

According toRogers and Shoemaker(in Nasution, 2014) agent of change is either an individual or instution that brings change to their community or surroundings. Agents of change pioneer, drive, and spread the process of change.

It is necessary for the agent of change to promote, prepare, and present or explain the plans of change, so that other people can understand, get attracted, and can demonstrate the change. In order to implement the change being proposed, the agents of change must help, serve, guide, and accompany the people surrounding; thus the plans of the change can be sustainably and independently implemented.

The agents of change must fulfill some sort of qualifications, including 1) technical qualification: agent of change must understand the specific projects of change, 2) administrative skill: the basic/ elementary skill of administration, 3) interpersonal skill: empathy, self-identification, shared perspective and intuition.

The agents of change function as the communication chains between two or more systems that pioneer social clients in formulating the change. Widyaiswara as the agent of change plays the role as: 1) catalyst, that drives and triggers society to change, 2) solution-maker, that creatively and innovatively seeks for solutions, 3) problem-solver, that assists solving the problems, giving directions, arranging needs, diagnosing and obtaining the source, planning the stages of problem solving, linking the related sources and solving them.

In doing their responsibilities, the agents of change do two kinds of approach: 1) Latent, a role that is not explicitly seen -as a leader, analyst, informant, intermediator, organizer, and evaluator 2) Manifest, a role that 'appears on the surface', consciously-acted and well-prepared -as a driving force/ trigger (facilitator, analyst, developer), an intermediary(informant and communicator), and a resolver (organizer, evaluator, and assessor).

Widyaiswaraas the agents of change are responsible to stimulate the willing to change, build a connection in terms of change, diagnose problems, trigger the needs for change, transform the needs for into the actions for change, sustain the change, and reach the target being set. 
Normatively, agents of change is legally regulated under PermenPAN and RB No 27 year 2014 aboutPedoman Pembangunan Agen Perubahan di Instansi Pemerintah; that it is necessary for an organization to have individuals or groups -either from the bottom to the top level- that play the role as the driving force that stimulize change, as well as the role model that reflect the values of organization. These groups and/or in dividuals are then called "The Agent of Change".

The agents of change are the selected individuals/groups that pioneer the change in organization. They also become the role models that reflect integrity and best performance in the organization.Individuals who are appointed as the agents of change are responsible for promoting certain roles assigned to them.

\section{Leadership Training Outcomes:-}

Promotions and Innovations are done by the participants of Leadership Training III and IV, from September to December 2015 in Badan Diklat Provinsi Jawa Timur (Bureau of Training and Development, East Java). Outcomes are presented as follows:

Leadership Training III Batch XXXV (APBD Prov Jatim), Seminar 17 November 2015.

\begin{tabular}{|c|c|c|c|c|c|}
\hline No & Name & $\begin{array}{c}\text { Position/ } \\
\text { Institution }\end{array}$ & Proper Title & $\begin{array}{c}\text { Type of } \\
\text { Innovation }\end{array}$ & Type of Promotion \\
\hline 1 & 2 & 3 & 4 & 5 & 6 \\
\hline 1. & $\begin{array}{c}\text { R. Henggar } \\
\text { Sulistiarto, } \\
\text { SH, MM }\end{array}$ & $\begin{array}{c}\text { Bureau of } \\
\text { Development } \\
\text { Administration / } \\
\text { Regional Secretariat } \\
\text { of East Java } \\
\end{array}$ & $\begin{array}{c}\text { Acceleration of } \\
\text { Goods/Servicces } \\
\text { Procurement through } \\
\text { Direct Procurement } \\
\text { (Electronic Application) }\end{array}$ & $\begin{array}{l}\text { Technology, } \\
\text { software/ } \\
\text { application for } \\
\text { auctions }\end{array}$ & $\begin{array}{l}\text { Indoor Socialization, } \\
\text { Technical guidance }\end{array}$ \\
\hline 2. & $\begin{array}{l}\text { Kartono } \\
\text { Umar, S.Pi, } \\
\text { MAP }\end{array}$ & $\begin{array}{c}\text { Technical } \\
\text { Facilitator } \\
\text { Unit(UPT) } \\
\text { Tamperan Seaport } \\
\text { Pacitan / } \\
\text { Department of } \\
\text { Marine and } \\
\text { Fisheries, East Java } \\
\end{array}$ & $\begin{array}{c}\text { UPT Service } \\
\text { Improvement in } \\
\text { Tamperan Pacitan } \\
\text { throughShip Docking }\end{array}$ & $\begin{array}{l}\text { Methods, } \\
\text { Fishermen's } \\
\text { Ship Repair }\end{array}$ & $\begin{array}{l}\text { Socialization, door to } \\
\text { door }\end{array}$ \\
\hline 3. & $\begin{array}{l}\text { Riyama } \\
\text { Budiawati }\end{array}$ & $\begin{array}{c}\text { Department of } \\
\text { Marine and } \\
\text { Fisheries, East Java }\end{array}$ & $\begin{array}{l}\text { Certfication of Fish } \\
\text { Cultivation (CBIB) } \\
\text { through Jemput Bola }\end{array}$ & $\begin{array}{l}\text { Service, } \\
\text { jemput bola }\end{array}$ & $\begin{array}{l}\text { Indoor socialization, } \\
\text { technical guidance, } \\
\text { benner, leafet, } \\
\text { mass/printed media }\end{array}$ \\
\hline 4. & $\begin{array}{c}\text { Endah } \\
\text { Kristiarni }\end{array}$ & $\begin{array}{c}\text { Technical } \\
\text { Facilitator } \\
\text { Unit(UPT) of } \\
\text { Marine Aquaculture } \\
\text { Situbondo / } \\
\text { Department of } \\
\text { Marine and } \\
\text { Fisheries, East Java }\end{array}$ & $\begin{array}{c}\text { Improvement of Applied } \\
\text { Research and } \\
\text { Technology } \\
\text { Dissemination on } \\
\text { Mariculture through the } \\
\text { Application of } \\
\text { Immunostimulants on } \\
\text { Tiger Grouper Hatchery } \\
\text { Feed }\end{array}$ & $\begin{array}{l}\text { Technology, } \\
\text { Feed mixtures }\end{array}$ & $\begin{array}{l}\text { Outdoor Socialization, } \\
\text { technical guidance, } \\
\text { benner, leafet }\end{array}$ \\
\hline 5. & $\begin{array}{l}\text { Hari Susilo, } \\
\text { SP, MP }\end{array}$ & $\begin{array}{c}\text { Technical } \\
\text { Facilitator } \\
\text { Unit(UPT) of } \\
\text { Horticultural } \\
\text { Breeding / } \\
\text { Department of } \\
\text { Agriculture, East } \\
\text { Java } \\
\end{array}$ & $\begin{array}{c}\text { Acceleration of } \\
\text { Horticultural Seeds Sales } \\
\text { through Marketing Mix }\end{array}$ & $\begin{array}{c}\text { Methods, } \\
\text { Marketing Mix }\end{array}$ & $\begin{array}{c}\text { Indoor \& Otdoor } \\
\text { Socialization, technical } \\
\text { guidance, benner, leafet, } \\
\text { mass/printed media, } \\
\text { radio, exhibition, } \\
\text { websites }\end{array}$ \\
\hline 6 & Fachrudin & $\begin{array}{c}\text { Department of } \\
\text { Public Works (PU) }\end{array}$ & $\begin{array}{c}\text { Reinforcement of Cliff } \\
\text { Embankment of }\end{array}$ & $\begin{array}{l}\text { Eco-friendly } \\
\text { Method } \\
\end{array}$ & $\begin{array}{l}\text { Indoor Socialization, } \\
\text { technical guidance }\end{array}$ \\
\hline
\end{tabular}




\begin{tabular}{|c|c|c|c|c|c|}
\hline & & $\begin{array}{c}\text { on Irrigation, East } \\
\text { Java / } \\
\text { Technical } \\
\text { Facilitator } \\
\text { Unit(UPT) ofWater } \\
\text { Resources } \\
\text { Management in } \\
\text { Lumajang }\end{array}$ & $\begin{array}{l}\text { Bondoyudo River } \\
\text { thorughVegetative } \\
\text { Method by Planting } \\
\text { Vetiver Grass }\end{array}$ & & \\
\hline 7 & $\begin{array}{l}\text { Moch.Jusron, } \\
\text { S.Sos, Msi }\end{array}$ & $\begin{array}{c}\text { Bureau of Public } \\
\text { Health } \\
\text { Administration / } \\
\text { Regional Secretariat } \\
\text { of East Java }\end{array}$ & $\begin{array}{c}\text { Revitalization } \\
\text { Programme on IT-based } \\
\text { Libary of Islamic Center }\end{array}$ & $\begin{array}{l}\text { Technology, } \\
\text { Software } \\
\text { application for } \\
\text { Library }\end{array}$ & $\begin{array}{l}\text { Indoor Socialization, } \\
\text { technical guidance }\end{array}$ \\
\hline 8 & $\begin{array}{l}\text { Dra. Endang } \\
\text { Sekar Wulan, } \\
\text { MM }\end{array}$ & $\begin{array}{c}\text { Bureau of Public } \\
\text { Relations and } \\
\text { Protocol, Regional } \\
\text { Secretariat of East } \\
\text { Java }\end{array}$ & $\begin{array}{l}\text { Improvement on } \\
\text { Information Service } \\
\text { Quality through the } \\
\text { Deployment of Printed } \\
\text { Media Clipping to SKPD } \\
\text { through Digitalization } \\
\text { System }\end{array}$ & $\begin{array}{l}\text { Technology, } \\
\text { Documentation } \\
\text { and } \\
\text { Information }\end{array}$ & $\begin{array}{l}\text { Indoor Socialization, } \\
\text { technical guidance }\end{array}$ \\
\hline 9 & $\begin{array}{c}\text { Imam } \\
\text { Asy'ari, MT }\end{array}$ & $\begin{array}{c}\text { Technical } \\
\text { Facilitator } \\
\text { Unit(UPT) of } \\
\text { Research } \\
\text { Laboratory on } \\
\text { Mineral and Water } \\
\text { Quality / } \\
\text { Beurau of Energy } \\
\text { and Mineral } \\
\text { Resources, East } \\
\text { Java }\end{array}$ & $\begin{array}{c}\text { Service Promotion on } \\
\text { Beurau of Energy and } \\
\text { Mineral Resources } \\
\text { Laboratory }\end{array}$ & $\begin{array}{l}\text { Process, } \\
\text { Services }\end{array}$ & $\begin{array}{l}\text { Indoor Socialization, } \\
\text { technical guidance, } \\
\text { banner, leafet, gathering, } \\
\text { web site }\end{array}$ \\
\hline
\end{tabular}

Leadership Training III Batch XXXI (City/District) Seminar 6 October 2015.

\begin{tabular}{|c|c|c|c|c|c|}
\hline No & Name & $\begin{array}{c}\text { Position/ } \\
\text { Institution }\end{array}$ & Proper Title & Type of Innovation & Type of Promotion \\
\hline 1 & 2 & 3 & 4 & 5 & 6 \\
\hline 10 & $\begin{array}{l}\text { Amiruddin, } \\
\text { S.Sos, } \\
\text { M.Si }\end{array}$ & $\begin{array}{c}\text { Proppo District, } \\
\text { Pamekasan } \\
\text { County }\end{array}$ & $\begin{array}{l}\text { 10-Minute Non- } \\
\text { Charge Service on } \\
\text { Integrated District } \\
\text { Administration } \\
\text { Services (PATEN) }\end{array}$ & $\begin{array}{c}\text { Process, Service on } \\
\text { PATEN }\end{array}$ & $\begin{array}{l}\text { Indoor Socialization, } \\
\text { banner }\end{array}$ \\
\hline 11 & $\begin{array}{c}\text { Sri Puja } \\
\text { Astutik, SE }\end{array}$ & $\begin{array}{l}\text { Board of Regional } \\
\text { Employment of } \\
\text { Pamekasan } \\
\text { County }\end{array}$ & $\begin{array}{l}\text { Administration } \\
\text { Services of Regional } \\
\text { Employment on } \\
\text { Remote Area }\end{array}$ & $\begin{array}{l}\text { Process, services on } \\
\text { remote areas }\end{array}$ & $\begin{array}{l}\text { Indoor Socialization, } \\
\text { banner }\end{array}$ \\
\hline 12 & $\begin{array}{c}\text { Ulung } \\
\text { Sedjati } \\
\text { Wirjawan, } \\
\text { ST }\end{array}$ & $\begin{array}{l}\text { Board of Research } \\
\text { and Development } \\
\text { of } \\
\text { Pasuruan County }\end{array}$ & $\begin{array}{c}\text { Batik Waste } \\
\text { Management on } \\
\text { Klampar Village, } \\
\text { Proppo District, } \\
\text { Pamekasan County }\end{array}$ & $\begin{array}{c}\text { Technology on Waste } \\
\text { Management }\end{array}$ & $\begin{array}{c}\text { Outdoor socialization, } \\
\text { banner }\end{array}$ \\
\hline 13 & $\begin{array}{l}\text { Ir.Moh. } \\
\text { Istamam, } \\
\text { Msi }\end{array}$ & $\begin{array}{l}\text { Departent of } \\
\text { Marine and } \\
\text { Fisheries, } \\
\text { Pamekasan } \\
\text { County }\end{array}$ & $\begin{array}{c}\text { Geoisolator } \\
\text { Technology to } \\
\text { Achieve Self- } \\
\text { Sufficiency of Salt } \\
\text { Farmers in Pamekasan }\end{array}$ & $\begin{array}{l}\text { Technology for Salt } \\
\text { Processing }\end{array}$ & $\begin{array}{c}\text { Outdoor socialization, } \\
\text { banner }\end{array}$ \\
\hline
\end{tabular}




\begin{tabular}{|c|c|c|c|c|c|}
\hline 14 & $\begin{array}{c}\text { Arifani } \\
\text { Yahya, SH }\end{array}$ & $\begin{array}{c}\text { Department of } \\
\text { Revenue, Finance, } \\
\text { and Asset } \\
\text { Management of } \\
\text { Mojokerto City }\end{array}$ & $\begin{array}{c}\text { Extra Service } \\
\text { Programme to } \\
\text { Accelerate } \\
\text { Disbursement of Tax } \\
\text { Arrears and Building } \\
\text { in Mojokerto City }\end{array}$ & $\begin{array}{c}\text { Process, Extra Public } \\
\text { Service without on } \\
\text { administrationfees }\end{array}$ & $\begin{array}{l}\text { Indoor \& outdoor } \\
\text { socialization, banner, } \\
\text { newspaper, mobil } \\
\text { keliling, press } \\
\text { conference }\end{array}$ \\
\hline 15 & $\begin{array}{l}\text { Dra. Ec. } \\
\text { Anna Sri } \\
\text { Asih, } \\
\text { M.Ak }\end{array}$ & $\begin{array}{l}\text { Regional Public } \\
\text { Hospital (RSUD) } \\
\text { Ibnu Sina } \\
\text { Gresik County }\end{array}$ & $\begin{array}{c}\text { Smart Cardfor Public } \\
\text { Health Service on } \\
\text { RSUD Ibnu Sina, } \\
\text { Gresik County }\end{array}$ & $\begin{array}{c}\text { Technology, Payment } \\
\text { card }\end{array}$ & $\begin{array}{c}\text { Indoor socialization, } \\
\text { banner, technical } \\
\text { guidance }\end{array}$ \\
\hline 16 & $\begin{array}{l}\text { Hidayatul } \\
\text { Muslimah, } \\
\text { SKM, MM }\end{array}$ & $\begin{array}{l}\text { Department of } \\
\text { Family Planning } \\
\text { (KB) and Women } \\
\text { Emancipation } \\
\text { (PP) } \\
\text { Gresik County }\end{array}$ & $\begin{array}{c}\text { Best Practicesfor } \\
\text { Holistic and } \\
\text { IntegrativeKelompok } \\
\text { Bina Keluarga } \\
\text { Balitain Gresik County }\end{array}$ & $\begin{array}{c}\text { Holistic and } \\
\text { integrative resources } \\
\text { management }\end{array}$ & $\begin{array}{l}\text { Indoor socialization, } \\
\text { banner }\end{array}$ \\
\hline 17 & $\begin{array}{l}\text { Drs. Nur } \\
\text { Hariyanto }\end{array}$ & $\begin{array}{l}\text { Board of Regional } \\
\text { Employment } \\
\text { Mojokerto City }\end{array}$ & $\begin{array}{l}\text { Online Employment } \\
\text { Services }\end{array}$ & $\begin{array}{l}\text { Technology, online } \\
\text { application/ software }\end{array}$ & $\begin{array}{c}\text { Indoor socialization, } \\
\text { banner, technical } \\
\text { guidance }\end{array}$ \\
\hline 18 & $\begin{array}{c}\text { Moh. } \\
\text { Nadlelah, } \\
\text { SP, M.Si }\end{array}$ & $\begin{array}{l}\text { Manyar District, } \\
\text { Gresik County }\end{array}$ & $\begin{array}{c}\text { Implementation of } \\
A P B D \text { Desa on Model } \\
\text { Village based on } U U \\
\text { Desa }\end{array}$ & $\begin{array}{l}\text { Method of APBD } \\
\text { Disposition }\end{array}$ & $\begin{array}{c}\text { Indoor socialization, } \\
\text { banner, technical } \\
\text { guidance }\end{array}$ \\
\hline 19 & $\begin{array}{l}\text { dr. } \\
\text { Mukhibatul } \\
\text { Khusnah, } \\
\text { MM }\end{array}$ & $\begin{array}{l}\text { Department of } \\
\text { Public Health, } \\
\text { Gresik County }\end{array}$ & $\begin{array}{l}\text { Exploring the Potential } \\
\text { of Public Participation } \\
\text { in the Promotion and } \\
\text { Preventive Control of } \\
\text { Non-Communicable } \\
\text { Diseases }\end{array}$ & $\begin{array}{c}\text { Resources } \\
\text { managementFormation } \\
\text { of partisipative group }\end{array}$ & $\begin{array}{l}\text { Indoor socialization, } \\
\text { banner, technical } \\
\text { guidance, door to door, } \\
\text { leaflet, mass } \\
\text { media/newspaper, } \\
\text { radio }\end{array}$ \\
\hline
\end{tabular}

Leadership Training III Batch XXXVII (Kota Pasuruan) seminar 1 December 2015.

\begin{tabular}{|c|c|c|c|c|c|}
\hline No & Name & $\begin{array}{c}\text { Position/ } \\
\text { Institution }\end{array}$ & Proper Title & $\begin{array}{c}\text { Type of } \\
\text { Innovation }\end{array}$ & Type of Promotion \\
\hline 1 & 2 & 3 & 4 & 5 & 6 \\
\hline 20 & $\begin{array}{l}\text { Yudhi } \\
\text { Harnendro, } \\
\text { SH, Msi }\end{array}$ & $\begin{array}{l}\text { Law Division, } \\
\text { Regional Secretariat } \\
\text { of Pasuruan City }\end{array}$ & $\begin{array}{c}\text { Issuance of Mayor } \\
\text { Regulation (Perwali) } \\
\text { Pasuruan on the } \\
\text { Guidelines of the } \\
\text { Establishment of Mayor } \\
\text { Regulation and } \\
\text { Resolution }\end{array}$ & $\begin{array}{l}\text { Product, } \\
\text { Regional } \\
\text { Regulation }\end{array}$ & $\begin{array}{l}\text { Indoor socialization, } \\
\text { banner, technical } \\
\text { guidance, legal drating }\end{array}$ \\
\hline 21 & $\begin{array}{l}\text { dr. Hendra } \\
\text { Romodhon }\end{array}$ & $\begin{array}{l}\text { Department of } \\
\text { Public Health, } \\
\text { Pasuruan City }\end{array}$ & $\begin{array}{l}\text { Model of Integrated } \\
\text { Polyclinic (Four Ways } \\
\text { of Healthy Soul) in } \\
\text { Puskesmas (Public } \\
\text { Health Center) }\end{array}$ & $\begin{array}{l}\text { Formation of } \\
\text { Organization } \\
\text { Structure of } \\
\text { Polyclinic }\end{array}$ & $\begin{array}{l}\text { Indoor socialization, } \\
\text { banner }\end{array}$ \\
\hline 22 & dr.Sudarmanto & $\begin{array}{l}\text { Regional Public } \\
\text { Hospital (RSUD) } \\
\text { dr.R.Soedarsono, } \\
\text { Pasuruan City }\end{array}$ & $\begin{array}{l}\text { Service Improvement in } \\
\text { Regional Public Hospital } \\
\text { (RSUD) dr. } \\
\text { R.Soedarsono through } \\
\text { Management } \\
\text { Information System }\end{array}$ & $\begin{array}{l}\text { Technology, } \\
\text { Software } \\
\text { application } \\
\text { for Hospital }\end{array}$ & Indoor socialization \\
\hline 23 & Mansur, S.Pt & $\begin{array}{c}\text { Department of } \\
\text { Youth, Sport, and } \\
\text { Culture, Pasuruan }\end{array}$ & $\begin{array}{l}\text { Transmission of } \\
\text { Information about } \\
\text { Heritage through }\end{array}$ & $\begin{array}{l}\text { Technology, } \\
\text { website }\end{array}$ & $\begin{array}{c}\text { Indoor socialization, } \\
\text { banner, televison, mass } \\
\text { media, newspaper, leafet }\end{array}$ \\
\hline
\end{tabular}




\begin{tabular}{|c|c|c|c|c|c|}
\hline & & City & $\begin{array}{c}\text { Content-Based on } \\
\text { Government Website }\end{array}$ & & \\
\hline 24 & $\begin{array}{c}\text { Imam Subekti, } \\
\text { S.Sos, MM }\end{array}$ & $\begin{array}{c}\text { Bureau of } \\
\text { Investment and } \\
\text { Integrated Licensing } \\
\text { Services, Pasuruan } \\
\text { City }\end{array}$ & $\begin{array}{c}\text { Acceleration of } \\
\text { Licensing Process } \\
\text { through Software } \\
\text { Application Si-Cepat }\end{array}$ & $\begin{array}{l}\text { Technology, } \\
\text { Software } \\
\text { application } \\
\text { for licensing }\end{array}$ & $\begin{array}{c}\text { Indoor socialization, } \\
\text { banner, televison, mass } \\
\text { media, newspaper, leafet }\end{array}$ \\
\hline 25 & Sunarno, SH & $\begin{array}{c}\text { Department of } \\
\text { Youth, Sport, and } \\
\text { Culture, Pasuruan } \\
\text { City }\end{array}$ & $\begin{array}{c}\text { Handling Street Children } \\
\text { with Persuasive } \\
\text { Approach and } \\
\text { Mentoring }\end{array}$ & $\begin{array}{c}\text { Resource } \\
\text { Management }\end{array}$ & $\begin{array}{l}\text { Indoor socialization, } \\
\text { banner }\end{array}$ \\
\hline 26 & $\begin{array}{l}\text { Fendi } \\
\text { Krisdiyono, } \\
\text { SP, MP }\end{array}$ & $\begin{array}{c}\text { Department of } \\
\text { Revenues, Pasuruan } \\
\text { City }\end{array}$ & $\begin{array}{l}\text { Facilitation of Online } \\
\text { Bookkeeping and Tax } \\
\text { Payment Report in } \\
\text { Pasuruan City }\end{array}$ & $\begin{array}{l}\text { Technology, } \\
\text { Online } \\
\text { Software } \\
\text { application } \\
\text { for Regional } \\
\text { Tax Payment }\end{array}$ & $\begin{array}{l}\text { Indoor socialization, } \\
\text { banner, door to door, } \\
\text { televison, mass media, } \\
\text { newspaper, leafet }\end{array}$ \\
\hline 27 & $\begin{array}{l}\text { Sri Rejeki } \\
\text { Andayani, } \\
\text { S.Sos }\end{array}$ & $\begin{array}{c}\text { Department of } \\
\text { Revenues, Pasuruan } \\
\text { City }\end{array}$ & $\begin{array}{c}\text { Transmission of } \\
\text { Information on BPHTB } \\
\text { Services through Social } \\
\text { Media }\end{array}$ & $\begin{array}{l}\text { Method of } \\
\text { Information } \\
\text { Transmission } \\
\text { of Regional } \\
\text { Tax } \\
\end{array}$ & $\begin{array}{l}\text { Banner, SMS, WA, } \\
\text { Website, newspaper, } \\
\text { indoor socialization }\end{array}$ \\
\hline 28 & $\begin{array}{l}\text { dr.Shierly } \\
\text { Marlena }\end{array}$ & $\begin{array}{l}\text { Department of } \\
\text { Public Health, } \\
\text { Pasuruan City }\end{array}$ & $\begin{array}{l}\text { Formation of Pilot } \\
\text { Project on Sanitation } \\
\text { Polyclinic in Public } \\
\text { Health Center } \\
\text { (Puskesmas) }\end{array}$ & $\begin{array}{c}\text { Formation of } \\
\text { Organization } \\
\text { Structure of } \\
\text { Puskesmas }\end{array}$ & $\begin{array}{l}\text { Banner, indoor and } \\
\text { outdoor socialization }\end{array}$ \\
\hline 29 & $\begin{array}{l}\text { Drs. Yohanes } \\
\text { Kasirin, S.Pd, } \\
\text { MM }\end{array}$ & $\begin{array}{c}\text { Department of } \\
\text { Youth, Sport, and } \\
\text { Culture, Pasuruan } \\
\text { City }\end{array}$ & $\begin{array}{c}\text { Enhancing Youth } \\
\text { Roleon Development } \\
\text { through Workshop } \\
\text { Wawasan Pemudaon } \\
\text { Highschool Students in } \\
\text { Pasuruan City }\end{array}$ & $\begin{array}{l}\text { Workshop } \\
\text { and } \\
\text { actualization } \\
\text { of } \\
\text { nationalism } \\
\text { values } \\
\end{array}$ & $\begin{array}{l}\text { Outdoor socialization, } \\
\text { newspaper, banner }\end{array}$ \\
\hline
\end{tabular}

Leadership Training IV Batch LXV (National) seminar 29 September 2015.

\begin{tabular}{|c|c|c|c|c|c|}
\hline No & Name & $\begin{array}{c}\text { Position/ } \\
\text { Institution }\end{array}$ & Proper Title & $\begin{array}{c}\text { Type of } \\
\text { Innovation }\end{array}$ & Type of Promotion \\
\hline 1 & 2 & 3 & 4 & 5 & 6 \\
\hline 30 & $\begin{array}{l}\text { Zulkifli, } \\
\text { S.Sos }\end{array}$ & $\begin{array}{c}\text { Inspectorate of North } \\
\text { Borneo }\end{array}$ & $\begin{array}{c}\text { Improvement on } \\
\text { Consulting Services } \\
\text { throughOnline Service } \\
\text { atInspectorate Blog om } \\
\text { Kaltara.Blogspot.Com }\end{array}$ & $\begin{array}{c}\text { Method, } \\
\text { online } \\
\text { service }\end{array}$ & Indoor socialization \\
\hline 31 & $\begin{array}{l}\text { Anang Dwi } \\
\text { Candra, ST }\end{array}$ & $\begin{array}{c}\text { Department of } \\
\text { Public Works and } \\
\text { Spatial (DPU \& TU), } \\
\text { North Borneo }\end{array}$ & $\begin{array}{c}\text { Participation } \\
\text { Improvement of } \\
\text { Private/State-owned } \\
\text { Companies } \\
\text { (Swasta/BUMN/D)in } \\
\text { Maximizing the } \\
\text { Function of Green- } \\
\text { Open-Space in Tanjung } \\
\text { Selor City through } \\
\text { Partnership with } \\
\text { Department of Public } \\
\text { Works \& Spatial (DPU }\end{array}$ & $\begin{array}{c}\text { Hubungan } \\
\text { Sumber Daya } \\
\text { antar } \\
\text { Governance }\end{array}$ & $\begin{array}{l}\text { Indoor socialization, } \\
\text { banner, door to door }\end{array}$ \\
\hline
\end{tabular}




\begin{tabular}{|c|c|c|c|c|c|}
\hline & & & $\begin{array}{c}\text { \& TU)North Borneo and } \\
\text { Department of Sanitary } \\
\text { \& Lanscaping Bulungan } \\
\text { County }\end{array}$ & & \\
\hline 32 & M. Faizal, ST & $\begin{array}{c}\text { Bureau of } \\
\text { Development and } \\
\text { Planning (Bappeda) } \\
\text { Paser County, North } \\
\text { Borneo }\end{array}$ & $\begin{array}{c}\text { Improving Budgetary } \\
\text { Quality } \\
\text { throughTechnical } \\
\text { Guidelines of } \\
\text { Infrastucture Planning } \\
\text { Evaluation System }\end{array}$ & $\begin{array}{c}\text { Process, } \\
\text { Service, } \\
\text { Technical } \\
\text { guideline- } \\
\text { based }\end{array}$ & Indoor socialization \\
\hline 33 & Brimadi, ST & $\begin{array}{c}\text { Department of } \\
\text { Public Works (DPU) } \\
\text { West Waringin City }\end{array}$ & $\begin{array}{c}\text { Guideline of Network } \\
\text { Operation } \\
\text { Maintenanceof Swamp } \\
\text { Reclamation }\end{array}$ & $\begin{array}{c}\text { Process, } \\
\text { maintenance } \\
\text { based on } \\
\text { Operation } \\
\text { Manual }\end{array}$ & $\begin{array}{c}\text { Indoor \& outdoor } \\
\text { socialization, banner }\end{array}$ \\
\hline 34 & Herman, ST & $\begin{array}{c}\text { Environmental } \\
\text { Agency, North } \\
\text { Borneo }\end{array}$ & $\begin{array}{c}\text { SOP Arragement for } \\
\text { Goods Management to } \\
\text { Improve the } \\
\text { Effectiveness of Goods } \\
\text { Management }\end{array}$ & $\begin{array}{c}\text { Process, } \\
\text { Goods } \\
\text { Management } \\
\text { based on } \\
\text { SOP }\end{array}$ & $\begin{array}{c}\text { Indoor \& outdoor } \\
\text { socialization, banner }\end{array}$ \\
& & & \multicolumn{2}{c}{} \\
\hline
\end{tabular}

\section{F.2 Application of Promotion Theory:-}

According to the theories, there are some kinds of promotions, include:

1. Advertising

2. Personal Selling

3. Sales Promotion

4. Public Relation/ Socialization

5. Publication

Those kinds of promotions are aimed to reach some fundamental objectives, including:

1. to Modify Behavior

2. to Inform

3. to Influence

4. to Remind

The application of promotion by the participants of Leadership Training are presented as follow:

\begin{tabular}{|l|l|r|l|l|}
\hline No & \multicolumn{1}{|c|}{ Type of Promotion } & \multicolumn{1}{c|}{ Amount } & \multicolumn{1}{c|}{ Embodiment } \\
\hline $\mathbf{1}$ & Advertising & 2 & $\mathbf{2 . 4}$ & Newspaper Articles \\
\hline $\mathbf{2}$ & Personal Selling & 12 & $\mathbf{1 4 . 4}$ & Door to door \\
\hline $\mathbf{3}$ & Sales Promotion & 2 & $\mathbf{2 . 4}$ & Exhibition \\
\hline $\mathbf{4}$ & Socialization & 43 & $\mathbf{5 1 . 9}$ & Meeting \\
\hline $\mathbf{5}$ & Publication & 24 & $\mathbf{2 8 . 9}$ & $\begin{array}{l}\text { Television, radio, banner, } \\
\text { newspaper, website }\end{array}$ \\
\hline & Total & $\mathbf{8 3}$ & $\mathbf{1 0 0 \%}$ & \\
\hline
\end{tabular}

Promotionsby Leadership Training participants are done and implemented simultaneosly. Those promotions are further conducted in accordance with the ideas of the organization's project of change. 
F.3. Application of Innovation Theory:-

The application of innovation by the participants of Leadership Training are presented as follow:

\begin{tabular}{|l|l|r|r|l|}
\hline No & \multicolumn{1}{|c|}{ Type of Innovation } & Amount & \multicolumn{1}{c|}{$\%$} & \multicolumn{1}{c|}{ Embodiment } \\
\hline 1 & Process & 23 & 27.7 & SOP, Guideline \\
\hline 2 & Method & 16 & 19.3 & Jemput bola \\
\hline 3 & Product & 1 & 1.2 & Outcomes \\
\hline 4 & Concept & - & & \\
\hline 5 & Technology & 27 & 32.5 & Application \\
\hline 6 & Organizational Structure & 2.4 & Addition of staff \\
\hline 7 & Relation & 13 & 15.7 & Coaching \\
\hline 8 & Human Development & 1.2 & Worskshop \\
\hline 9. & Others & - & & \\
\hline & TOTAL & $\mathbf{8 3}$ & $\mathbf{1 0 0 \%}$ & \\
\hline
\end{tabular}

Innovations by Leadership Training participants are done and implemented simultaneosly. Those promotions are further conducted in accordance with the ideas of the organization's project of change.

\section{Conclusion:-}

Widyaiswaraare known as the agents of change for their roles as the driving force that stimulize change, as well as the role model that reflect the values of organization.

Widyaiswara as the agents of change are responsible to stimulate the willing to change, build a connection in terms of change, diagnose problems, trigger the needs for change, transform the needs for into the actions for change, sustain the change, and reach the target being set.

Widyaiswara pioneer the change within organization. They also become the role models that reflect integrity and best performance in the organization. Individuals/groups who are appointed as the agents of change are responsible for promoting the ideas of innovation within organization.

\section{References:-}

1. W. Lawrence Neuman, Social Research Methods: Qualitative and Quantitative Approaches,(Needham Heights, MA: Allyn\& Bacon, 1997), hlm. 14

2. John W. Creswell, Research Design: Qualitative and Quantitative Approaches, (California: SagePublications, Inc, 1994), hlm. 5.

3. Djamaludin, Ancok. 2012. Psikologi Kepemimpinan \& Inovasi. Jakarta: Erlangga

4. Handbook Inovasi Administrasi Negara, LAN 2014, Penulis Tim Pusat Inovasi Tata Pemerintahan, Lembaga Administrasi Negara, Jakarta

5. Peraturan Perundangan-undangan :

6. PermenPAN dan Reformasi Birokrasi ( Permen PAN \& RB ) Nomor 11 Tahun 2015 tentang Road Map Reformasi Birokrasi 2015-2019

7. PermenPAN dan RB No 27 Tahun 2014 tentang Pedoman Pembangunan Agen Perubahan di Instansi Pemerintah

8. Peraturan Kepala Lembaga Administrasi Negara Nomor 19 Tahun 2015 Tentang Pedoman Penyelenggaraan Pendidikan Dan Pelatihan Kepemimpinan Tingkat III

9. Peraturan Kepala Lembaga Administrasi Negara Nomor 20 Tahun 2015

10. Tentang Pedoman Penyelenggarjaan Pendidikan Dan Pelatihan Kepemimpinan Tingkat IV. 